Kamil Trombik

\title{
JAK RODZIŁA SIE FILOZOFIA NA PAPIESKIEJ AKADEMII TEOLOGICZNEJ W KRAKOWIE? ZARYS HISTORYCZNY DO ROKU 1991*
}

\section{PHILOSOPHY AT THE PONTIFICAL ACADEMY OF THEOLOGY IN KRAKÓW. HISTORICAL OUTLINE BY 1991}

\author{
Zazwyczaj ktoś inny dzieje tworzy, ktoś inny je pisze, \\ a często jeszcze ktoś inny nad nimi rozmyśla, szukając \\ ich ostatecznego sensu i najdalszych, trwałych motorów. \\ Konstanty Michalski
}

Mija czterdzieści lat od wydania przez Kongregację Wychowania Katolickiego Dekretu ustanawiającego Papieski Wydział Filozoficzny w Krakowie. To z pewnością dobra okazja do kilku refleksji i podsumowań dotychczasowej działalności tego ośrodka. W tym krótkim szkicu historycznym ograniczę się jednak przede wszystkim do prezentacji wczesnego okresu

* Niniejsza praca powstała $\mathrm{w}$ ramach programu badawczego, finansowanego z Własnego Funduszu Stypendialnego Uniwersytetu Papieskiego Jana Pawła II w Krakowie (stypendium badawcze na realizację tematu „Filozofia na Papieskiej Akademii Teologicznej w Krakowie. Studium historyczno-analityczne obejmujące lata 1976-1991”). 
funkcjonowania wydziału, zamykając poniższe opracowanie na omówieniu pierwszej dekady jego istnienia. Skoro tak, to od razu rodzić może się pytanie: skąd zawarty w tytule rok 1991, a nie 1986? Nie uprzedzając zbyt wiele, zaznaczę jedynie w tym miejscu, że kluczowe znaczenie dla działalności Wydziału Filozoficznego odegrał kolejny akt Stolicy Apostolskiej, bazujący na wspomnianym Dekrecie. Chodzi o motu proprio Jana Pawła II „Beata Hedvigis” ustanawiające Papieską Akademię Teologiczną w Krakowie - które nosi datę 8 grudnia 1981 roku. O tym, dlaczego akurat ten dokument okazał się w tym kontekście przełomowy, będzie jeszcze mowa ${ }^{1}$.

Wypada jednak zacząć od uwagi, iż historia Wydziału Filozoficznego powiązana jest siecią zależności z dziejami Uniwersytetu Jagiellońskiego. Powołana w 1981 roku Papieska Akademia Teologiczna (obecnie nosząca nazwę Uniwersytet Papieski Jana Pawła II w Krakowie) wraz z funkcjonującym w jej obrębie ośrodkiem filozoficznym wywodzą się bowiem z działalności dawnego Wydziału Teologicznego Uniwersytetu Jagiellońskiego, założonego w 1397 roku i pozostającego częścią najstarszej polskiej uczelni aż do roku 1954. Tego rodzaju historyczne powiązanie między dwoma ośrodkami naukowymi rodzi oczywiście szereg pytań, także w kontekście interesującego nas tutaj tematu. Nasuwa się chociażby problem, jak przebiegało kształtowanie się myśli filozoficznej w krakowskim środowisku uczonych katolickich po usunięciu Wydziału Teologicznego z Uniwersytetu Jagiellońskiego w 1954 roku. Czy miało ono charakter ciągły, również w aspekcie organizacyjnym, stanowiąc kontynuację działalności dawnej jednostki naukowej? Czy można zatem mówić, biorąc pod uwagę wspomniane zależności, także o jakichś źródłach ideowych filozofii uprawianej na Papieskiej Akademii Teologicznej? Jak wreszcie rozwijała się działalność naukowo-dydaktyczna krakowskich filozofów katolickich w okresie poprzedzającym faktyczne ukonstytuowanie się Wydziału Filozoficznego? Jak funkcjonowanie tegoż ośrodka wyglądało we wczesnym okresie jego istnienia? Z powyższymi pytaniami przyjdzie się jeszcze mierzyć

${ }^{1}$ Jak każdy zarys, tak i poniższy tekst miejscami może wydać się selektywny pod kątem dobranego materiału źródłowego. Pewne rozwiązania metodologiczne mogą sprawiać wrażenie arbitralnych, z drugiej strony trudno na tym etapie badań o jednoznaczne kryteria, którymi należałoby się kierować przy opracowywaniu szkicu do dziejów tak złożonych, jak dzieje Wydziału Filozoficznego obecnego Uniwersytetu Papieskiego Jana Pawła II. Mam jednak nadzieję, że sposób prezentacji, jaki został przeze mnie obrany, okaże się wystarczający dla zrekonstruowania najistotniejszych i najbardziej charakterystycznych aspektów działalności naukowej oraz dydaktycznej krakowskiego ośrodka filozoficznego, tworzącego od 1981 roku Wydział Filozoficzny Papieskiej Akademii Teologicznej. 
w dalszych partiach opracowania, choć wypada przyznać, iż kilka wstępnych założeń i rozstrzygnięć $\mathrm{w}$ związku z podniesionymi kwestiami zostało już poczynionych. Widoczne to będzie chociażby w układzie artykułu.

Przyjmując bowiem już na wstępie, iż mimo wszystko można wskazać na korzenie ideowe Wydziału Filozoficznego Papieskiej Akademii Teologicznej oraz że tkwią one w poglądach uczonych związanych z dawną jednostką teologiczną Uniwersytetu Jagiellońskiego, konieczne wydaje się choćby skrótowe sięgnięcie myślą do pierwszych postaci, które kształtowały w obrębie tego ośrodka refleksję filozoficzną, rozwijając ją tam zwłaszcza po 1882 roku. Z tego właśnie względu, w pierwszym rozdziale pokrótce przedstawię sylwetki kilku uczonych-filozofów, którzy kładli podwaliny pod formujące się w czasach powojennych katolickie środowisko filozoficzne w Krakowie. Pomimo niechęci władz komunistycznych, środowisko to tworzyło w latach sześćdziesiątych i siedemdziesiątych XX wieku zręby organizacyjne dla przyszłego Wydziału Filozoficznego. Prezentacji wysiłków owego grona osób poświęcono rozdział drugi opracowania. W trzeciej, głównej części artykułu skupię się na dziejach nowszych, począwszy od dokumentu erygującego Papieski Wydział Filozoficzny na bazie Papieskiego Wydziału Teologicznego (działającego po roku 1954 do ogłoszenia motu proprio „Beata Hedvigis”), a następnie na działalności tego ośrodka już w ramach Papieskiej Akademii Teologicznej.

Sama struktura proponowanego opracowania wskazuje, że wypowiadając się o początkach Wydziału Filozoficznego, należy mówić bardziej jako o pewnym procesie niż o jednostkowym wydarzeniu. Procesie, który w dodatku zainaugurowany został, przynajmniej ideowo, nie czterdzieści, a ponad sto trzydzieści lat temu. Z jakimi okolicznościami się wiązał? Czy wydarzenia mające miejsce niemalże wiek przed rokiem 1976 rzeczywiście zapoczątkowały proces, którego zwieńczeniem jest między innymi dzisiejsza rocznica?

\section{Rodowód (1882-1954)}

Refleksja filozoficzna gościła na Wydziale Teologicznym Uniwersytetu Jagiellońskiego właściwie od momentu jego powstania. Szczególny rozwój filozofii uprawianej w duchu chrześcijańskim nastąpił jednak w krakowskiej uczelni zwłaszcza po ogłoszeniu encykliki Aeterni Patris w 1879 roku. W dokumencie tym papież Leon XIII nawoływał do odnowy spuścizny filozoficznej św. Tomasza z Akwinu w celu „ochrony i ozdoby wiary katolickiej, dla dobra 
społeczeństwa, dla rozwoju wszystkich dyscyplin naukowych"2. Papieskie przesłanie dotyczące znaczenia refleksji filozoficznej w uprawianiu teologii nie pozostało w Krakowie bez odzewu. Już w 1882 roku utworzono w obrębie Wydziału Teologicznego UJ Katedrę Filozofii Chrześcijańskiej, pierwszą tego rodzaju jednostkę uniwersytecką na ziemiach monarchii austro-węgierskiej, do której należał wówczas Kraków ${ }^{3}$. Prowadzenie katedry powierzono ks. Stefanowi Pawlickiemu CR (1839-1916), uczonemu, który uchodzić może za jednego z pionierów nowoczesnej myśli chrześcijańskiej w Polsce, kształtowanej w oparciu o wzorce starożytnej filozofii i akceptującej osiągnięcia nauk przyrodniczych $^{4}$. Znamienne w postawie naukowej Pawlickiego okazało się odchodzenie - przynajmniej w takim stopniu, w jakim to było możliwe po Soborze Watykańskim I i wspomnianej encyklice Leona XIII - od tradycyjnej scholastyki ${ }^{5}$. Jednym z głównych celów działalności naukowej krakowskiego uczonego było budowanie filozofii otwartej na przyrodoznawstwo, akceptującej najnowsze zdobycze wiedzy i przygotowanej do rzetelnego dialogu z nauką. Drogą do realizacji tego zadania miało być między innymi specjalistyczne wykształcenie. Wszak „filozof - jak pisał Pawlicki - jeżeli ma uchronić się niepotrzebnych spekulacji i zboczeń zdrowego rozsądku, powinien choć w jednej nauce specjalnej być znawcą"6. Trudno powstrzymać się od komentarza, iż tego typu podejście do filozofii, jak na owe czasy, cechowało się odwagą i innowacyjnością ${ }^{7}$.

${ }^{2}$ Leon XIII, Encyklika „Aeterni Patris”, nr 31.

${ }^{3}$ Por. S. Piech, Dzieje Wydziału Teologicznego Uniwersytetu Jagiellońskiego w latach 18801939, Kraków 1995, s. 114; Cz. Głombik, Początki neoscholastyki polskiej, Katowice 1991.

${ }^{4}$ Choć - gwoli ścisłości - warto przy tym zwrócić uwagę, że Pawlicki nie zgadzał się ze wszystkim, co proponowali przedstawiciele ówczesnej nauki, np. polemizował na kartach „Przeglądu Lwowskiego" z ewolucjonizmem. Por. S. Pawlicki, Studyja nad darwinizmem, Kraków 1875.

${ }^{5}$ Barbara Skarga zauważa, iż Pawlicki był przeciwnikiem odrodzenia scholastyki i utożsamiania jej z filozofią katolicką. Por. B. Skarga, Lata 1864-1895, w: A. Walicki (red.), Zarys dziejów filozofii polskiej 1815-1918, Warszawa 1983, s. 246.

${ }^{6}$ S. Pawlicki, Kilka uwag o podstawie i granicach filozofii, Kraków 1878, s. 81. Znamienne, że podobne postulaty wysuwał kilka dekad później K. Twardowski, twórca szkoły lwowsko-warszawskiej. Por. K. Twardowski, Jak studiować filozofię, w: tenże, Rozprawy i artykuly filozoficzne, Lwów 1927, s. 175.

${ }^{7}$ Warto jednak uzupełnić tę uwagę o stwierdzenie, iż w pewnym sensie podejście Pawlickiego nawiązywało do wzorców filozoficznych, płynących - z pewnymi wyjątkami - od czasów antycznych aż do rozwoju tak zwanej „romantycznej filozofii przyrody” na przełomie XVIII i XIX wieku. Por. S. Pawlicki, Kilka uwag..., dz. cyt., s. 65-81; M. Heller, Filozofia przyrody. Zarys historyczny, Kraków 2007, s. 129-148. 
Zarówno Pawlicki, jak i jego następcy, czyli ks. Franciszek Gabryl (18661914), ks. Konstanty Michalski CM (1879-1947), ks. Jan Salamucha (19031944) czy ks. Aleksander Usowicz CM (1912-2002), kładli podwaliny pod filozofię próbującą ukazać spójny obraz szeroko rozumianej kultury oraz wiary. Choć zasadniczo bezpośredni kontynuatorzy ks. Pawlickiego pozostawali myślicielami głęboko zakorzenionymi w tradycji tomistycznej, zarówno pod względem stosowanej metody, jak i podzielanych zainteresowań badawczych, cechowało ich również otwarcie na pytania płynące ze strony współczesności. I tak na przykład ks. Gabryl okazał się nie tylko „najlepszym znawcą i wyznawcą myśli neoscholastycznej”, ale również filozofem, który „idąc za tomizmem i szkołą lowańską, zajmował często w poglądach swych stanowisko kompromisowe między różnymi zapatrywaniami scholastyków", ostrożnie poszukując nowych rozwiązań tradycyjnych zagadnień filozoficznych ${ }^{9}$. Główny obszar zainteresowań Gabryla wyznaczały problemy z zakresu metafizyki, filozofii przyrody, psychologii racjonalnej i antropologii filozoficznej. Z kolei ks. Michalski, o którym Roman Ingarden pisał swego czasu, iż „był najwybitniejszym, jak dotąd, polskim historykiem filozofii, a zarazem pierwszym w Polsce uczonym, który badania w zakresie historii filozofii postawił na prawdziwie europejskim poziomie"10, kładł akcent na pogłębienie refleksji nad dziejami rodzimej i zachodniej myśli filozoficznej ${ }^{11}$, nierzadko przekraczając w swoich pracach granice wyznaczone przez metodę tomistyczną (stąd niekiedy bywa zaliczany do tzw. tomizmu otwartego).

Natomiast Salamucha, związany z II Katedrą Filozofii Chrześcijańskiej (powołaną do istnienia w okresie międzywojennym), podobnie jak Michalski interesował się zagadnieniami historycznymi, zwłaszcza logiką starożytną i średniowieczną. Czerpiąc z tradycji szkoły lwowsko-warszawskiej, nawią-

${ }^{8}$ Por. K. Michalski, Stanowisko ks. Gabryla w ruchu neoscholastycznym, „Ateneum Kapłańskie", t. 13 (1917), s. 46-56.

${ }^{9}$ Por. A. Usowicz, Gabryl Franciszek (1866-1914), w: W. Kopczyński (red.), Polski Słownik Biograficzny, t. 7, Kraków 1948-1958, s. 193-194.

${ }^{10}$ R. Ingarden, Ks. Konstanty Michalski. Uczony - filozof - człowiek, „Tygodnik Powszechny” 34 (1947), s. 1. Podobną opinię wyrażało wielu innych myślicieli, np. B. Gawecki pisał o Michalskim jako o „uczonym na skalę europejską”. Por. B. Gawecki, Pięćdziesiąt lat filozofii w Krakowie, „Przegląd Filozoficzny” 44 (1948), s. 32.

${ }^{11}$ Aleksander Usowicz wyodrębnił w dorobku Michalskiego teksty mediewistyczne z zakresu polskiej myśli scholastycznej, filozofii zachodniej XIV wieku oraz myśli Dantego. Por. A. Usowicz, Życie i dzieła ks. Konstantego Michalskiego, w: A. Usowicz, K. Kłósak, Ksiądz Konstanty Michalski (1879-1947), Kraków 1949, s. 109. 
zywał w swoich badaniach systematycznych do najnowszych osiągnięć logiki formalnej. Był również w latach trzydziestych współtwórcą tak zwanego Koła Krakowskiego, którego członkowie - m.in. o. Józef Maria Bocheński i Jan Franciszek Drewnowski - usiłowali inicjować nowoczesne rozwiązania związane z problematyką metodologii filozofii i teologii ${ }^{12}$.

Nietrudno więc zauważyć, że rozległość zainteresowań wspomnianych uczonych Wydziału Teologicznego Uniwersytetu Jagiellońskiego była znacząca, a ich dorobek naukowy okazał się prekursorski dla działających po II wojnie światowej myślicieli chrześcijańskich. Być może właśnie owa wszechstronność, a także otwarcie na współczesność i skłonność do przekraczania granic u tych kilku uczonych okazały się istotnymi czynnikami w procesie przetrwania środowiska katolickich filozofów w Krakowie w drugiej połowie XX wieku, kształtując przy tym klimat intelektualny, z którego czerpać mogli następnie tacy myśliciele, jak ks. Józef Tischner, ks. Michał Heller czy ks. Józef Życiński.

Ostatnim kierownikiem I Katedry Filozofii Chrześcijańskiej - już po roku 1945 - został ks. Aleksander Usowicz, następca i uczeń Michalskiego. Główny ton spuściźnie pisarskiej tego myśliciela nadawały zagadnienia, które umieścić należałoby w kontekście teorii bytu, psychologii racjonalnej i filozofii społecznej. Krakowski uczony dostrzegał jednak - podobnie zresztą jak jego poprzednicy - związki między różnymi dziedzinami filozofii, a także między filozofią a szeroko rozumianą kulturą współczesną. Z tego względu skłaniał się ku bardzo wszechstronnym badaniom, poruszając nawet problemy przypisywane tradycyjnie etyce, antropologii filozoficznej czy logice ${ }^{13}$.

Ks. Usowicz nie miał jednak okazji rozwijać chrześcijańskiej refleksji filozoficznej w obrębie Uniwersytetu Jagiellońskiego. Choć jeszcze w 1953 roku recenzował rozprawę habilitacyjną Karola Wojtyły, to już rok później stanął - wraz z całym gronem uczonych katolickich, wśród których znalazł się m.in. filozof przyrody ks. Kazimierz Kłósak (1911-1982), znany wtedy z polemik

${ }^{12}$ Z. Wolak, Naukowa filozofia Koła Krakowskiego, w: M. Heller, J. Mączka, P. Polak, M. Szczerbińska-Polak (red.), Krakowska filozofia przyrody w okresie międzywojennym. Tom pierwszy: początki, Kraków-Tarnów 2007, s. 41-62; K. Świętorzecka, Jan Salamucha (19031944), w: B. Listkowska, A. Andrzejuk (red.), Tomizm polski 1919-1945. Słownik filozofów, Radzymin 2014, s. 73-79.

${ }^{13}$ Od tej ostatniej zaczynał zresztą swoją ścieżkę naukową, broniąc na Angelicum w Rzymie rozprawę doktorską o teorii definicji w dziełach Arystotelesa. Bardziej szczegółowe informacje biograficzne por. np. M. Markowski, Aleksander Usowicz - wielki uczony i dobry nauczyciel przełomowych czasów, „Informator Instytutu Teologicznego Księży Misjonarzy” 22 (2002), s. 25-77; T. Pawlikowski, Filozofia teoretyczna ks. Aleksandra Usowicza, Kraków 2012, s. 13-36. 
z materializmem dialektycznym ${ }^{14}$ - wobliczu bolesnej decyzji władz PRL, mocą której usunięto Wydział Teologiczny z Uniwersytetu Jagiellońskiego, włączając go wstrukturę Akademii Teologii Katolickiej w Warszawie. Krakowscy uczeni katoliccy stanęli wówczas przed trudnym wyzwaniem: kontynuować działalność pomimo odgórnych rozporządzeń czy też pogodzić się $\mathrm{z}$ zastaną sytuacją? Ostatecznie wybrano pierwsze rozwiązanie, co nie tylko dla teologów, ale także dla filozofów katolickich związanych z Krakowem miało niebagatelne znaczenie. Ideowymi spadkobiercami tradycji zapoczątkowanej przez Pawlickiego i jego następców już wkrótce okazać się mieli uczeni, którzy po 1954 roku podjęli się organizacji „nowej” uczelni i nowego ośrodka filozoficznego w jej obrębie. Czy ich starania przyniosły pożądany skutek? W kontekście obchodzonej rocznicy istnienia Wydziału Filozoficznego Uniwersytetu Papieskiego Jana Pawła II pytanie może wydać się retoryczne, choć trzeba od razu zaznaczyć, że droga do obecnej sytuacji wiodła przez liczne trudności i wymagała czasu, a zwłaszcza cierpliwej, żmudnej pracy wielu uczonych, których połączyła nadzieja na efektywną kontynuację działalności filozoficzno-teologicznej w niełatwych czasach dyktatury komunistycznej.

\section{Okres przejściowy (1954-1976)}

Władze Polskiej Rzeczypospolitej Ludowej uchwała z dnia 11 sierpnia 1954 roku zadecydowały o tym, iż „z Uniwersytetu Jagiellońskiego w Krakowie wyodrębnia się Wydział Teologii Katolickiej, który (...) kontynuować będzie swą działalność w ramach Akademii Teologicznej w Warszawie"15. W efekcie część pracowników podjęła tymczasową pracę na ATK, jednak de facto pozostała związana z Krakowem i tutaj kontynuowała działalność dydaktyczno-naukową. Dawny Wydział Teologiczny UJ stracił co prawda uznanie cywilne władz państwowych, jednak dzięki zdecydowanej postawie Stolicy

${ }^{14}$ Por. K. Kłósak, Materializm dialektyczny. Studia krytyczne, Kraków 1948. Książka ks. Kłósaka była pierwszą w powojennej Polsce pracą polemiczną, w której - między innymi w oparciu o osiągnięcia przyrodoznawstwa - podjęto próbę zdyskredytowania podstawowych założeń materializmu dialektycznego, jakie wyrażane były zwłaszcza w pracach A. Schaffa. Co ciekawe, książka (stanowiąca rozwinięcie artykułów publikowanych wcześniej na łamach „Znaku”, „Ateneum Kapłańskiego” i „Tygodnika Powszechnego”) spotkała się z odpowiedzią ze strony marksistów. Głos na jej temat zabrał np. młody Leszek Kołakowski. Por. L. Kołakowski, Metodologia ks. Kłósaka - felieton filozoficzny, „Myśl Filozoficzna” 1-2 (1951), s. 316-322.

${ }^{15}$ Uchwała Rady Ministrów z dnia 11 sierpnia 1954 r., w: Państwowe prawo wyznaniowe Polskiej Rzeczpospolitej Ludowej, zebrał M. Fąka, Warszawa 1978, s. 124-125. 
Apostolskiej oraz biskupów krakowskich nadal istniał i działał, podlegając władzy kościelnej. Świadectwem tego stanu rzeczy okazał się przede wszystkim Dekret Kongregacji Seminariów i Studiów Uniwersyteckich z dnia 16 grudnia 1959 roku, który potwierdzał istnienie Wydziału Teologicznego „pod zarządem jednego Zwierzchnictwa Kościelnego"16. Dla krakowskich uczonych był to ważny dokument, który w dodatku motywował do podejmowania starań o odzyskanie praw państwowych. Równocześnie prowadzono już autonomiczną działalność w oparciu o ustawodawstwo kościelne. Dyscypliny filozoficzne, jako fundamentalne w procesie kształcenia przyszłych teologów, rozwijane były nadal przez filozofów takich jak ks. Usowicz czy ks. Kłósak, przez co zachowana została ciągłość tradycji. Warto zauważyć, że jeszcze w planie zajęć obowiązujących w roku akademickim 1953/54 (a więc w ostatnim roku przed decyzją władz PRL) na Wydziale Teologicznym UJ uwzględnione były zajęcia z filozofii chrześcijańskiej prowadzone przez księży Usowicza i Kłósaka w wymiarze łącznym 420 godzin dla I i II roku studiów ${ }^{17}$. Z kolei w planie „Studium Domesticum" Arcybiskupiego Seminarium Duchownego w Krakowie, opracowanego dla roku akademickiego 1954/1955, filozofia odgrywała nie mniej znaczącą rolę. Uwzględniano wykłady z historii filozofii, logiki, metafizyki, teorii poznania, kosmologii, psychologii, a także etyki społecznej ${ }^{18}$.

W latach sześćdziesiątych ośrodek krakowski kontynuował działalność, od czasu Soboru Watykańskiego II (1962-1965) stosując tytuł „papieski” w swojej nazwie. Początkowo dawny Wydział Teologiczny UJ funkcjonował więc pod nazwą Papieski Fakultet Teologiczny, a od 1968 roku jako Papieski Wydział Teologiczny. Tytuł, który pojawił się w celu umocnienia pozycji wydziału w stosunku do władz państwowych, był tolerowany przez Stolicę Apostolską, choć oficjalna decyzja w kwestii nazewnictwa pojawiła się dopiero w 1974 roku $^{19}$. Warto zwrócić uwagę na to, iż okres lat sześćdziesiątych wią-

${ }^{16}$ Dekret Świętej Kongregacji Seminariów i Studiów Uniwersyteckich $z$ dnia 16 grudnia 1959 roku, w: J. Morawa, S. Postawa (red.), Jubileusz sześćsetlecia Wydziału Teologicznego w Krakowie: 20.10.1996-20.10.1997, Kraków 1998, s. 161.

${ }^{17}$ Por. A. Kubiś, Papieski Wydział Teologiczny w Krakowie w latach 1954-1981, Kraków 2005, s. 28-29.

${ }^{18}$ Tamże, s. 78-79.

${ }^{19}$ Dekret Kongregacji Wychowania Katolickiego, nadający Wydziałowi Teologicznemu w Krakowie tytuł „papieski”, wydany został 2 czerwca 1974 roku. Por. A. Kubiś, Papieski Wydział Teologiczny w Krakowie (1954-1981), w: K. Majka (red.), Wyższe szkolnictwo kościelne w Polsce. Wizja Ks. Kard. Karola Wojtyly i jej realizacja, Kraków 2002, s. 11; tenże, Papieski Wydział Teologiczny w Krakowie w latach 1954-1981, dz. cyt., s. 183. 
że się także ze stopniowym wzmacnianiem struktur tego ośrodka naukowego i rozwojem środowiska filozoficznego w jego obrębie. Po Vaticanum II środowisko to składało się już z kilku uczonych specjalizujących się w różnych dziedzinach filozofii. Oprócz księży Kłósaka i Usowicza wymienić należy tutaj ks. Tadeusza Wojciechowskiego (1917-2000), ks. Mariana Jaworskiego (ur. 1926), ks. Józefa Tischnera (1931-2000) czy ks. Tadeusza Ślipko SJ (1918-2015).

W drugiej połowie lat sześćdziesiątych, w trakcie posiedzeń Rad Papieskiego Wydziału Teologicznego dyskutowane były między innymi zmiany programowe, które objąć miały nie tylko nauczanie przedmiotów teologicznych, ale również filozoficznych. Wystąpiono wówczas z propozycją utworzenia tak zwanych zespołów wykładowych, w ramach których koordynowany miał być dobór i zakres wykładanego materiału. Projekt przyjęto i wyłoniono pięć zespołów, wśród których znalazła się grupa filozoficzna. Jej przewodniczącym został ks. Kłósak, sekretarzem ks. Wojciechowski, zaś pozostałymi członkami księża Jaworski, Ślipko, Tischner i Usowicz ${ }^{20}$.

Modyfikacje programowe dały wkrótce początek zmianom strukturalnym. W 1969 roku podjęto decyzję o podziale wydziału na sekcje i katedry ${ }^{21}$. Niedługo później, bo w 1970 roku, zadecydowano o utworzeniu trzech sekcji, które w założeniu miały być punktem wyjścia do tworzenia nowych wydziałów ${ }^{22}$. Obok sekcji teologicznej i prawa kanonicznego wyłoniono sekcję filozofii. Pierwsze poważne kroki w celu powołania odrębnej jednostki filozoficznej można więc upatrywać $\mathrm{w}$ ówczesnych postanowieniach. Zarządzono wtedy, że w ramach każdej sekcji tworzone zostaną kierunki badawcze, które posłużą do wyodrębnienia katedr jako jednostek naukowo-dydaktyczych. Z sekcji filozofii wyłoniono ostatecznie osiem katedr' ${ }^{23}$ : 1. Katedra logiki formalnej, ogólnej metodologii nauk i teorii poznania (kierownik: ks. K. Kłósak), 2. Katedra metafizyki, filozofii Boga i filozofii religii (ks. M. Jaworski), 3. Katedra antropologii filozoficznej (vacat: kurator ks. K. Kłósak), 4. Katedra psychologii ogólnej

${ }^{20}$ Archiwum Uniwersytetu Papieskiego Jana Pawła II w Krakowie (dalej: ArUPJPII), PWT-0022: Protokoły z posiedzeń Rad Wydziału, t. 1 (25.06.1963-05.04.1968), Protokół z posiedzenia Rady Wydziału z dnia 9.12.1966 roku, k. 40.

${ }^{21}$ ArUPJPII, Protokoly..., t. 2 (10.06.1968-25.06.1974), Protokół z posiedzenia Rady Wydziału z dnia 5.12.1969 roku, k. 45.

${ }^{22}$ ArUPJPII, Protokoly..., t. 2, Załacznik nr 1 do protokołu z posiedzenia Rady Wydziału $z$ dnia 31.01.1970 roku, k. 51.

${ }^{23}$ ArUPJPII, Protokoly..., t. 2, Protokół z posiedzenia Rady Wydziału z dnia 30.01.1970 roku, k. 47; tamże, Załącznik nr 2 do protokotu z posiedzenia Rady Wydziału z dnia 30.01.1970 roku, k. 54; A. Kubiś, Papieski Wydział Teologiczny w Krakowie w latach 1954-1981, dz. cyt., s. 101. 
(ks. T. Wojciechowski), 5. Katedra psychologii rozwojowej i wychowawczej (ks. S. Bizuń), 6. Katedra filozofii przyrodoznawstwa i filozofii przyrody ( $v a-$ cat: kurator ks. K. Kłósak), 7. Katedra etyki (vacat: kurator ks. T. Ślipko SJ), 8. Katedra historii filozofii (ks. A. Usowicz).

Świadectwem rozwoju Papieskiego Wydziału Teologicznego była również organizacja dwuletnich studiów przywydziałowych, przeznaczonych dla duchownych i świeckich. Celem działalności tych studiów miało być pogłębienie u słuchaczy wiedzy w zakresie aktualnych zagadnień teoretycznych i duszpasterskich $^{24}$. Słuchacze, po spełnieniu określonych warunków, mogli uzyskać stopień magistra teologii. Inicjatywa powołania tego rodzaju działalności dydaktycznej wyszła ze strony kard. Karola Wojtyły. Początkowy projekt przedstawiony przez niego w 1968 roku obejmował powołanie czterech Studiów Przywydziałowych: Liturgicznego, Rodziny, Katechetycznego i Myśli Współczesnej ${ }^{25}$. To ostatnie - określane także jako Studium Dialogu - miało mieć charakter studium filozoficznego, a jego organizację powierzono ks. Jaworskiemu ${ }^{26}$. Ten jednak ostatecznie nie podjął się realizacji tego zadania. Kierownictwo Studium przeszło więc w ręce ks. Tischnera, cenionego już wówczas filozofa, znanego z osiągnięć na polu fenomenologii i krytycznego stosunku do filozofii tomistycznej ${ }^{27}$. Jego zastępcą został mianowany Stanisław Grygiel.

Studium Myśli Współczesnej rozpoczęło działalność w roku 1973. W jednym z najwcześniejszych zawiadomień, pochodzącym z października tego roku, Tischner zaznaczał, że

celem studium jest pogłębienie wiedzy o współczesnych prądach filozoficznych pod kątem potrzeb dialogu. Myśl współczesna - jak wiadomo - jest niekiedy bardzo daleka od chrześcijaństwa, często staje do niego w opozycji, częściej jednak znajduje się w orbicie jego promieniowania, a nawet przyciągania. Zadaniem studium jest nie tylko ukazanie przeciwieństw między światem a chrześcijaństwem i przygotowanie na tej drodze rzetelnej polemiki, lecz przede wszystkim odsłonięcie utajonych podobieństw i wspólnych dążeń. Studium zamierza w ten sposób przygotować pole do dialogu ze współczesnością, a także samo chce w takim dialogu uczestniczyć. Studium zasadniczo

${ }^{24}$ ArUPJPII, Protokoły..., t. 2, Załacznik do protokołu z posiedzenia Rady Wydziału z dnia 21 czerwca 1969 roku, k. 28.

${ }^{25}$ ArUPJPII, Protokoły..., t. 2, Protokół z posiedzenia Rady Wydziału z dnia 7.11.1968 roku, k. 11,12 .

${ }^{26}$ ArUPJPII, Protokoty..., t. 2, Protokół z posiedzenia Rady Wydziału z dnia 16.05.1970 roku, k. 55.

${ }^{27}$ Por. J. Tischner, Schyłek chrześcijaństwa tomistycznego, „Znak” 1 (1970), s. 1-26. 
posiada charakter filozoficzny. Jego program koncentruje się wokół trzech podstawowych tematów: współczesnej filozofii Boga, współczesnej filozofii człowieka oraz współczesnej filozofii przyrody. Przewidziany jest również wykład z zakresu aktualnej tematyki teologicznej ${ }^{28}$.

Zajęcia odbywały się co miesiąc w czwarty wtorek, w sali konferencyjnej udostępnianej przez kard. Wojtyłę. W ramach Studium organizowano wykłady, dyskusje, seminaria, a także spotkania z cenionymi przedstawicielami myśli współczesnej: naukowcami, pisarzami, artystami. Jak pisał Tischner, „są to niekiedy ludzie stojący $\mathrm{z}$ dala od chrześcijaństwa. W ten sposób chcemy nie tylko uczyć dialogu, lecz również sami we własnym zakresie prowadzić go i rozwijać" ${ }^{29}$. Co istotne, absolwenci Wydziałów lub Instytutów Teologicznych, którzy ukończyli pomyślnie Studium, mieli możliwość uzyskania stopnia magistra teologii ze specjalności „filozofia chrześcijańska” ${ }^{30}$.

Wykład inaugurujący działalność Studium, zatytułowany „Dialog w myśli współczesnej”, został wygłoszony przez Tischnera 23 października 1973 roku $^{31}$. Studia rozpoczęło 12 studentów. Program zajęć objął wówczas zagadnienia z zakresu filozofii człowieka (ks. J. Tischner, S. Grygiel), filozofii przyrody (ks. T. Wojciechowski, ks. M. Heller), filozofii społecznej (ks. R. Darowski SJ), filozofii religii (ks. M. Jaworski) i problematyki teologiczno-bibiljnej (ks. J. Chmiel, ks. A. Jankowski). Wśród zaproszonych gości znaleźli się Stanisław Lem, Maria Dłuska, Bogusław Winid i Stefan Kisielewski. W roku akademickim 1973/74 w ramach Studium zorganizowano także Sympozjum „Katolicyzm - romantyzm - Z. Krasiński”32.

Kierowane przez ks. Tischnera Studium Myśli Współczesnej stało się w kolejnych latach - aż do roku 1984, kiedy zakończyło działalność - przestrzenią dla pogłębionego dyskursu filozoficznego. W gronie jego wykładowców znalazło się wielu późniejszych pracowników Wydziału Filozoficznego, między innymi ks. Tadeusz Gadacz SP, o. Jan Andrzej Kłoczowski OP, ks. Józef Makselon,

${ }^{28}$ ArUPJPII, PWT-012: Informacje 1973-1979 (Studium Myśli Współczesnej), Informacja ks. J. Tischnera o Przywydziałowym Studium Myśli Współczesnej PWT (Kraków, 9.10.1974), s. 1.

${ }^{29}$ ArUPJPII, PWT-400: Programy-propozycje 1973-1983 (Studium Myśli Wspótczesnej), Zawiadomienie o Przywydziałowym Studium Myśli Współczesnej PWT, kierowane do duchownych i osób świeckich (Kraków, 1.10.1974), s. 8.

${ }^{30}$ Tamże.

${ }^{31}$ ArUPJPII, PWT-4300: Dziennik zajęć Studium Myśli Wspótczesnej, s. 2.

${ }^{32}$ ArUPJPII, PWT-0323: Sprawozdania (Studium Myśli Współczesnej), Sprawozdanie $z$ dnia 17.04.1975, s. 2,3. 
ks. Roman Rożdżeński, Karol Tarnowski, ks. Tadeusz Wojciechowski, ks. Józef Życiński. Tematyka zajęć prowadzonych w Pałacu Arcybiskupim przy ulicy Franciszkańskiej 3 skupiała się wokół zagadnień z zakresu filozofii człowieka, etyki, filozofii Boga, filozofii przyrody i współczesnej myśli teologicznej. Dyskutowane były np. kwestie związane z filozofią dialogu, zjawiskiem ateizmu, teorią ewolucji, relacją „nauka a religia”. Poruszano tematy dotyczące tanatopsychologii, manipulacji nad ludzkim mózgiem, a także religijności - i to nie tylko w aspekcie filozoficznym, ale również psychologicznym. Debatowano także o szeroko rozumianej wolności, ideologii, koncepcji pracy w ujęciu biblijnym czy stosunkiem chrześcijaństwa do marksizmu. Studium organizowało ponadto sympozja i spotkania $\mathrm{z}$ osobami reprezentującymi różne dyscypliny naukowe i stanowiska światopoglądowe, jak np. Józefa Hennelowa, Tadeusz Żychiewicz czy Bohdan Cywiński.

Początki działalności Studium Myśli Współczesnej zbiegły się także w czasie ze staraniami ks. kard. Karola Wojtyły w sprawie powołania Wydziału Filozoficznego w Krakowie. Pierwotne zamierzenia w tej kwestii zakładały współpracę ze środowiskiem krakowskich jezuitów. Planowano połączyć Wydział Filozoficzny Księży Jezuitów z Papieskim Wydziałem Teologicznym celem stworzenia wspólnego, dwuwydziałowego „Atheneum”. Próba ta jednak nie powiodła się, jezuici nie zaakceptowali bowiem warunków postawionych przez Kongregację Wychowania Katolickiego oraz Wielkiego Kanclerza $\mathrm{PWT}^{33}$. Z drugiej strony, środowisko jezuitów nadal pozostawało otwarte na współpracę akademicką, między innymi poprzez podejmowanie wspólnych wykładów $^{34}$. W efekcie Papieski Wydział Teologiczny zaprosił w 1973 roku do prowadzenia zajęć z antropologii filozoficznej ks. Romana Darowskiego SJ, a także ks. Ludwika Piechnika SJ, który podjął wykłady z pedagogiki. Wkrótce wymiana profesorów między dwoma krakowskimi ośrodkami filozoficznymi miała przerodzić się w owocny zwyczaj.

W trakcie obrad Rady PWT w dniu 14 listopada 1975 roku ówczesny prodziekan ks. Tadeusz Pieronek szczegółowo omawiał kwestie związane z powołaniem Wydziału Filozoficznego, zaznaczając, iż przygotowania w tej sprawie weszły w stadium końcowe ${ }^{35}$. W związku z powstaniem nowej jednostki w ob-

${ }^{33}$ A. Kubiś, Papieski Wydział Teologiczny w Krakowie w latach 1954-1981, dz. cyt., s. 212.

${ }^{34}$ ArUPJPII, Protokoły..., t. 2, Protokół z posiedzenia Rady Wydziału z dnia 4.10.1973 roku, k. 209.

${ }^{35}$ ArUPJPII, Protokoty..., t. 3 (3.10.1974-24.06.1977), Protokót z posiedzenia Rady Wydziału $z$ dnia 14.11.75, k. 79. 
rębie wydziału i - co za tym idzie - planowanymi zmianami w jego strukturze, wysunięty został pomysł zmiany dotychczasowej nazwy z Papieskiego Wydziału Teologicznego na Papieską Akademię Krakowską ${ }^{36}$. Tego samego dnia, tj. 25 lutego 1976 roku kard. Karol Wojtyła po raz kolejny mocno akcentował potrzebę istnienia nowego ośrodka filozoficznego. Omawiał także dotychczasowe poczynania w tej kwestii, stwierdzając, że Konferencja Episkopatu Polski upoważniła go do działania według własnego rozeznania ${ }^{37}$. Dość powiedzieć, że podejmowane wysiłki przyniosły wkrótce oczekiwany rezultat. 23 grudnia 1976 Kongregacja Wychowania Katolickiego wydała mianowicie Dekret ustanawiający Papieski Wydział Filozoficzny w Krakowie.

\section{Trudne początki (1976-1991)}

Decyzja Stolicy Apostolskiej o powołaniu Wydziału Filozoficznego nie przyniosła natychmiastowej zmiany sytuacji, a realizacja Dekretu - ze względu na trudności stawiane przez władze komunistyczne - odbywała się etapami. Mimo to jeszcze w 1977 roku poproszono ks. Tischnera, aby podjął się organizacji specjalistycznych studiów filozoficznych ${ }^{38}$. Równolegle prowadzone były także dyskusje w szerszym gronie pracowników PWT, dotyczące spraw organizacyjnych formułującego się ośrodka naukowego. Decyzją Rady Wydziału z 17 lutego 1978 roku powołano ostatecznie jednak tylko Instytut Filozofii przy Papieskim Wydziale Teologicznym, który w czasie swojej kilkuletniej działalności de facto „stanowił jednostkę nieformalną" ${ }^{\text {”39 }}$. Mimo to zatrudniono wówczas dwóch świeckich wykładowców, którzy mieli wzmocnić działającą do tej pory grupę filozofów. W ten sposób z krakowskim Instytutem Filozofii przy PWT, nad którym kierownictwo objął ks. Tischner, związali się Karol Tarnowski i Stanisław Grygiel. k. 142.

${ }^{36}$ ArUPJPII, Protokoły..., t. 3, Protokół z posiedzenia Rady Wydziału z dnia 25.02.1976,

${ }^{37}$ Tamże.

${ }^{38}$ ArUPJPII, Protokoły, t. 4 (4.10.1977-23.01.1981), Protokół z posiedzenia Rady Wydziału $z$ dnia 4.10.1977, k. 7.

${ }^{39}$ A. Kubiś, Papieski Wydział Teologiczny (1954-1981), dz. cyt., s. 14. Por. także A. Kubiś, J. Szczutek, Nowy etap (1981-1997), w: S. Piech (red.), Wydział Teologiczny w Krakowie 19371997. Księga jubileuszowa, Kraków 1997, s. 231-232; A. Kubiś, Papieska Akademia Teologiczna na tle ogólnej sytuacji nauki katolickiej w Polsce, „Biuletyn Papieskiej Akademii Teologicznej w Krakowie" 4 (1985/86), s. 19-20. 
Ważnym wydarzeniem w dziejach Papieskiego Wydziału Teologicznego była wizyta Karola Wojtyły - tym razem już jako Jana Pawła II - w Krakowie. W czasie spotkania z Radą Wydziału 9 czerwca 1979 roku Papież nawiązywał w swoim przemówieniu do aktualnej sytuacji, w jakiej znalazł się nowy ośrodek filozoficzny:

Zgoda Stolicy Apostolskiej wyrażona pismem z 23 grudnia 1976 roku dotyczy powołania w Papieskiej uczelni krakowskiej Wydziału Filozoficznego jako odpowiadającego rzeczywistym potrzebom środowiska. Ze względu na znane okoliczności, ażeby nie utrudniać rozmów prowadzonych pomiędzy Stolicą Apostolską a rządem PRL, zgoda ta nie została na razie opublikowana. Natomiast stosownie do meritum wyżej wymienionego pisma, uczelnia zaczęła wprowadzać w cały system studiów specjalizację akademicką w dziedzinie filozofii, wyodrębniając na razie całokształt studiów tej dziedziny w formie odrębnego Instytutu ${ }^{40}$.

Warto dodać, że prowadzone wówczas rozmowy z przedstawicielami władzy przyniosły niedługo później kilka pomyślnych rezultatów, między innymi zezwolono na ubezpieczenie pracowników naukowych Wydziału i zniesiono cenzurę na nazwę „Papieski Wydział Teologiczny w Krakowie”, o czym dziekan (ks. M. Jaworski) poinformował Radę Wydziału 14 listopada 1980 roku $^{41}$.

Szczęśliwe zwieńczenie starań w sprawie powołania Wydziału Filozoficznego nastąpiło dopiero w 1981 roku. 8 grudnia, a więc 5 dni przed wprowadzeniem w Polsce stanu wojennego, papież Jan Paweł II wydał motu proprio „Beata Hedvigis”, na mocy którego ustanowiono Papieską Akademię Teologiczną, składającą się z trzech wydziałów - w tym Wydziału Filozoficznego. Dokument papieski nadawał wydziałom Akademii prawo nadawania stopni akademickich od magisterium, poprzez licencjat i doktorat, aż po habilitację $e^{42}$. Ze względu na stan wojenny promulgowanie „Beata Hedvigis” nastąpiło jednak dopiero 24 marca 1982 roku podczas posiedzenia Rady Wydziału. Postanowiono wówczas, że Papieska Akademia Teologiczna rozpocznie działalność dydaktyczną i naukową w roku akademickim 1982/83 ${ }^{43}$.

${ }^{40}$ ArUPJPII, Protokoly..., t. 4, Tekst przemówienia Ojca św. Jana Pawła II w czasie spotkania $z$ Rada Papieskiego Wydziału Teologicznego dnia 9.06.1979 r., k. 137.

${ }^{41}$ ArUPJPII, Protokoły..., t. 4, Protokót z posiedzenia Rady Wydziału w dniu 14.11.1980, k. 250.

${ }^{42}$ Por. Jana Paweł II, List apostolski motu proprio „Beata Hedvigis”, w: Jubileusz sześćsetlecia..., dz. cyt., s. 162-165.

${ }^{43}$ A. Kubiś, Papieski Wydział Teologiczny w Krakowie (1954-1981), dz. cyt., s. 46. 
Warto jednak mieć na uwadze, iż jeszcze przed 1982 rokiem środowisko krakowskich uczonych skupionych wokół Instytutu Filozofii prowadziło zaawansowane prace na polu naukowo-dydaktycznym. Od roku akademickiego 1978/79 organizowano przy Papieskim Wydziale Teologicznym wykłady z różnych dziedzin filozofii, nadal funkcjonowało także Studium Myśli Współczesnej. Powiększała się kadra naukowa, organizowano również sympozja i wykłady dla gości spoza Polski. Ważnym wydarzeniem było na przykład międzynarodowe spotkanie filozofów na temat „The Human Person and Philosophy in the Contemporary World", zorganizowane w Krakowie w dniach 23-25 sierpnia $1978 \mathrm{roku}^{44}$. Wykład pt. Filozofia a literatura wygłosił z kolei w 1979 roku Hans-Georg Gadamer, jeden z najwybitniejszych przedstawicieli hermeneutyki filozoficznej. Przykłady te pokazują, że środowisko krakowskich filozofów Papieskiego Wydziału Teologicznego nawiązywało współpracę z uczonymi na całym świecie.

Działalność Instytutu Filozofii wiąże się również z inicjatywą znaną pod nazwą konwersatoriów interdyscyplinarnych, które od 1978 roku organizowane były przez ks. Michała Hellera i ks. Józefa Życińskiego. Spotkania te zainaugurowały niedługo później działalność Ośrodka Studiów Interdyscyplinarnych ${ }^{45}$, którego celem było między innymi prowadzenie badań w zakresie filozofii przyrody, filozofii i historii nauki, relacji „nauka a religia”. Konwersatoria Interdyscyplinarne miały swoją bogatą tradycję sięgającą inicjatyw kard. Wojtyły, który w latach siedemdziesiątych gromadził w Krakowie uczonych różnych dyscyplin na nieformalne spotkania dyskusyjne o różnych problemach z zakresu nauki oraz kultury. Konwersatoria organizowane przez Hellera i Życińskiego nawiązywały do tych zwyczajów; w spotkaniach zainaugurowanych w 1978 roku brali udział liczni uczeni - nie tylko filozofowie i teologowie, ale również biologowie, fizycy czy matematycy - którzy dyskutowali na tematy z pogranicza filozofii, nauki, wiary i sztuki. Prelegenci i słuchacze spotykali się początkowo przy ulicy Franciszkańskiej 3 w pierwszy piątek po piętnastym dniu każdego miesiąca, a gdy grono uczestników zaczęło się powiększać (bywało, że wykładów słuchało nawet 200 osób), przeniesiono spotkania do

${ }^{44}$ Por. J. Życiński (red.), The Human Person and Philosophy in the Contemporary World. Proceedings of the Meeting of the World Union of Catholic Philosophical Societies. Cracow, 23-25 August 1978, Kraków 1980.

${ }^{45}$ Nazwa „Ośrodek Badań Interdyscyplinarnych” zaczęła pojawiać się od dwunastego numeru czasopisma „Zagadnienia Filozoficzne w Nauce” z roku 1990. Por. M. Heller, Po 20-stu latach, „Zagadnienia Filozoficzne w Nauce” 25 (1999), s. 7. 
klasztoru augustianów. Pomimo kiepskich warunków lokalowych, braku środków finansowych i statutów, a przy tym wobec niechęci władz państwowych do Kościoła, środowisko filozoficzne przy Papieskim Wydziale Teologicznym rozwijało się nad wyraz dobrze, stanowiąc „wyraźny prymat ducha nad materią"46. Jak pisał ks. Włodzimierz Skoczny, świadek tamtych spotkań, „umiejętność niedostrzegania niedociągnięć, a zauważania jedynie pozytywów została przez uczestników dopracowana do perfekcji. W rzeczy samej trudno jest dziś oddać niepowtarzalną atmosferę tamtych dni. Coś nieuchwytnego unosiło się w powietrzu, coś co miało posmak wyrzeczenia, przyjaźni i Prawdy" ${ }^{37}$.

Konwersatoria organizowano w dwóch cyklach tematycznych: „Nauka wiara” (w latach 1978-1991 oraz 1992-1993) oraz „Nauka - filozofia - sztuka" (1983-1985). Wśród prelegentów znajdowali się znakomici goście z kraju i zagranicy, m.in. Stefan Amsterdamski, Zygmunt Chyliński, Stanisław Lem, Jerzy Rayski, o. Jacek Salij OP, Leszek Sokołowski, Andrzej Staruszkiewicz, ks. Jan Twardowski czy Jan Woleński z Polski, a spoza ojczyzny np. Charles W. Misner, Alvin Plantinga, Carl Friedrich von Weizsäcker ${ }^{48}$. Organizowane wówczas spotkania przedstawicieli nauki i filozofii zaowocowały powstaniem periodyku „Zagadnienia Filozoficzne w Nauce”, który ukazywał się pod redakcją Hellera i Życińskiego jako rocznik ${ }^{49}$. Oprócz działalności związanej z konwersatoriami, czasopismem oraz wydawaniem publikacji książkowych (często we współpracy ze Specola Vaticana oraz Polskim Towarzystwem Teologicznym) Ośrodek Studiów Interdyscyplinarnych organizował także sympozja i wykłady tematyczne. W latach 1981-1991 odbyły się następujące konferencje: „The Gallileo Affair: A Meeting of Faith and Science” (1984), „Newton and the New Direction in Science” (1987), „Dlaczego przyroda jest matematyczna?” (1989), „Spór o uniwersalia a nauka współczesna” (1990), „Relacja nauka - wiara w katechezie. Problematyka ewolucji” (1991), „Theology, Philosophy and Cosmology: on West and East" (1991). Wśród zaproszonych gości znajdowali się m.in. George V. Coyne SJ, Paul K. Feyerabend czy Frank J. Tipler. W latach

${ }^{46}$ Por. W. Skoczny, Spotkania OBI widziane „od kuchni”, „Zagadnienia Filozoficzne w Nauce" 25 (1999), s. 13-15.

${ }^{47}$ Por. tamże.

${ }^{48}$ Więcej szczegółów por. Z. Liana, J. Mączka, Z kroniki OBI, „Zagadnienia Filozoficzne w Nauce" 25 (1999), 133-155.

${ }^{49} \mathrm{~W}$ czasopiśmie pojawiały się nie tylko materiały z konwersatoriów, ale również recenzje książek czy przekłady tekstów takich filozofów, jak np. J. Ladrière, I. Lakatos, K. Popper czy A.N. Whitehead. Warto dodać, że czasopismo ukazuje się po dzień dzisiejszy, pod redakcją naukową P. Polaka, M. Hellera, J. Mączki i P. Urbańczyka. 
1990-1991 zorganizowano ponadto dwa cykle „Coyne Lectures”, których tytuł nawiązywał do listu, jaki Jan Paweł II skierował do George’a Coyne’a z okazji trzechsetnej rocznicy wydania Principiów Newtona, zachęcając w nim do budowania mostów między nauką a wiarą. Z tej okazji wykłady w Krakowie wygłosili Olaf Pedersen oraz Robert Sokolovski.

Aktywność środowiska filozofów przyrody, rozwijająca się jeszcze w okresie istnienia Instytutu Filozofii, była jak widać kontynuowana w latach osiemdziesiątych, gdy istniał już Wydział Filozoficzny Papieskiej Akademii Teologicznej. Ośrodek ten, jak już wcześniej powiedziano, zainaugurował swoją działalność w roku akademickim 1982/83 (co ciekawe, przypadła wówczas setna rocznica objęcia przez ks. Pawlickiego Katedry Filozofii Chrześcijańskiej na Uniwersytecie Jagiellońskim), przyjmując do grona studentów 20 osób. Pierwszym dziekanem wydziału został dotychczasowy kierownik Instytutu Filozofii i zarazem prodziekan istniejącego wcześniej Papieskiego Wydziału Teologicznego, ks. Józef Tischner ${ }^{50}$. Specyfikę działalności naukowej nowo powstałej jednostki odzwierciedlać miał Statut uczelni z 1983 roku, w którym podkreślono, iż „celem Wydziału Filozoficznego jest uprawianie i rozwijanie nauk filozoficznych w oparciu o właściwą im metodę i przysługującą im wolność badań naukowych, zarówno dla głębszego zrozumienia prawd podstawowych dla człowieka i jego życia, jak i dla dociekań teologicznych oraz wspierania dialogu ze światem" ${ }^{51}$. Sprecyzowano także formę kształcenia, przyjmując tryb trzystopniowy, tj. czteroletnie studia podstawowe, a także roczne cykle dla licencjatu i doktoratu, które prowadzono w ramach sekcji specjalizujących się w określonych tematach badawczych (do wyboru były sekcje filozofii poznania, metafizyki, filozofii człowieka i filozofii przyrody).

W sprawozdaniu za pierwszy rok działalności ks. Adam Kubiś informował, że Wydział Filozoficzny liczył łącznie - wraz z osobami przejętymi z Instytutu Filozofii - 74 studentów, zaś na prawach wolnych słuchaczy uczestniczyło w zajęciach 81 osób $^{52}$. Kolejne lata upływały pod znakiem dalszego rozwoju. Przybywało studentów, powiększała się również struktura wydziału.

${ }^{50}$ Prace administracyjne przy Wydziale Filozoficznym powierzono wówczas dr. J. Steckiewiczowi, a następnie Elżbiecie Jordan.

${ }^{51}$ Statut Wydziału Filozofii PAT, pkt 1, w: Statut Papieskiej Akademii Teologicznej w Krakowie, oprac. J. Dyduch, Kraków 1992, s. 94.

${ }^{52}$ A. Kubiś, Sprawozdanie z 1/586 roku działalności Papieskiej Akademii Teologicznej w Krakowie, „Biuletyn Papieskiej Akademii Teologicznej w Krakowie” 2 (1983/84), s. 31. 
Jeszcze w roku akademickim 1983/84 tworzyło go dziewięć katedr ${ }^{53}$, natomiast kilka lat później jednostek naukowo-dydaktycznych było już trzynaście ${ }^{54}$. Niezależnie od istniejącego Ośrodka Studiów Interdyscyplinarnych tworzyły się nowe grupy badawcze. I tak na przykład dzięki inicjatywom ks. Krzysztofa Szczygła w roku 1987 powstał Międzywydziałowy Instytut Bioetyki, pierwszy tego typu ośrodek w Polsce ${ }^{55}$. Oprócz tego Wydział Filozoficzny podejmował także współpracę na polu naukowym $\mathrm{z}$ licznymi instytucjami zza granicy, jak The Catholic University of America (Waszyngton, USA), Université Catholique de Louvain (Belgia), Specola Vaticana (Castel Gandolfo) czy Institut für die Wissenschaften vom Menschen w Wiedniu. Na polu dydaktycznym realizowano umowę o współpracę z Wydziałem Filozoficznym Towarzystwa Jezusowego i z Kolegium Filozoficzno-Teologicznym OO. Dominikanów. Zapraszano licznych gości przy okazji różnych konferencji i sympozjów, organizowanych przez wydział, poświęconych m.in. filozofii dialogu („Rozum i Słowo”, 14-15 maja 1987), problematyce religii („Z problematyki współczesnej filozofii religii”, 16-18 listopada 1988), tematyce społecznej i antropologicznej („Wolność a odpowiedzialność”, 11-12 października 1989), kwestiom bioetycznym („Problematyka AIDS”, 23 lutego 1990) czy filozofii bytu („Metafizyka na rozdrożu”, 24-25 października 1991).

Widać zatem, że kolejni po Tischnerze dziekani, tj. Tadeusz Wojciechowski (kadencja w okresie między 1985 a 1988 rokiem) oraz Józef Życiński (19881991), wraz z szerokim gronem kadry naukowej, stopniowo organizowali

${ }^{53}$ Wykaz katedr wraz z kierownikami: Katedra Metafizyki i Filozofii Religii (ks. M. Jaworski), Katedra Filozofii Człowieka (ks. J. Tischner), Katedra Psychologii (ks. T. Wojciechowski), Katedra Filozofii Przyrody Ożywionej (p.o. ks. T. Wojciechowski), Katedra Filozofii Przyrody Nieożywionej (ks. M. Heller), Katedra Historii Filozofii Starożytnej i Średniowiecznej (ks. A. Usowicz), Katedra Historii Filozofii Nowożytnej i Współczesnej (p.o. K. Tarnowski), Katedra Filozofii Poznania (p.o. ks. J. Tischner), Katedra Logiki i Metodologii (ks. J. Życiński). Por. Papieska Akademia Teologiczna w Krakowie. Wydział Filozofii: informator 1983/84, Kraków 1983, s 7-8.

${ }^{54}$ Katedra Metafizyki i Filozofii Boga, Katedra Filozofii Religii, Katedra Filozofii Człowieka, Katedra Psychologii Ogólnej, Katedra Psychologii Rozwojowej i Wychowawczej, Katedra Psychologii Religii, Katedra Filozofii Przyrody Ożywionej, Katedra Filozofii Przyrody Nieożywionej, Katedra Filozofii Poznania, Katedra Filozofii Nauki, Katedra Logiki, Katedra Historii Filozofii Starożytnej i Średniowiecznej, Katedra Filozofii Nowożytnej i Współczesnej.

${ }^{55}$ Por. T. Biesaga, Bioetyka na Papieskiej Akademii Teologicznej w kontekście jubileuszu 80-lecia urodzin ks. prof. Krzysztofa Szczygła i 20-lecia założonego przez niego Międzywydziałowego Instytutu Bioetyki, w: J. Brusiło (red.), Historia i przyszłość bioetyki. Tom dedykowany ks. prof. Krzysztofowi Szczygłowi z okazji 80-lecia urodzin, Kraków 2009, s. 25-35. 
działalność Wydziału Filozoficznego, kształtując jego specyfikę wobec innych tego typu ośrodków w Polsce. Można zaryzykować stwierdzenie, że w okresie pierwszej dekady istnienia Papieskiej Akademii Teologicznej wyklarowały się w jej obrębie cztery główne grupy badawcze o największych tradycjach, prowadzące w swoich dziedzinach najbardziej zaawansowane prace naukowe w zakresie filozofii. Grupy te koncentrowały się na problematyce 1. filozofii człowieka (reprezentowanej przez ks. J. Tischnera i jego współpracowników: ks. T. Gadacza SP, ks. A. Jarnuszkiewicza SJ, ks. J. Gorczycę SJ, A. Bobko, Z. Stawrowskiego), 2. filozofii religii i Boga (ks. M. Jaworski, K. Tarnowski, o. J.A. Kłoczowski OP, ks. A. Smandek CM, ks. W. Paluchowski CM), 3. filozofii przyrody i nauki (ks. M. Heller, ks. J. Życiński, ks. T. Wojciechowski, A. Michalik, ks. P. Lenartowicz SJ, o. M. Pieńkowski OP, M. Szydłowski, ks. W. Skoczny, ks. Z. Liana) oraz 4. psychologii (ks. T. Wojciechowski, o. H. Piszkalski CSsR, ks. J. Makselon, o. W. Chaim CSsR) ${ }^{56}$. Dodać należy, że stopniowo formowały się także inne tradycje badawcze, związane z etyką (ks. W. Zuziak), bioetyką (ks. K. Szczygieł), filozofią społeczną (ks. S. Pamuła, Z. Stawrowski) czy filozofią poznania (ks. R. Rożdżeński). Kontynuowane były badania z zakresu historii filozofii i filozofii bytu (ks. A. Usowicz CM, o. S. Bafia CSsR, A. Szwed, ks. A. Żak SJ), rozwijano również prace dotyczące filozofii analitycznej i filozofii języka (A. Gawroński).

Spośród wyróżnionych nurtów badawczych Wydziału Filozoficznego na szczególną uwagę zasługują dwa, które cieszyły się największym uznaniem środowiska naukowego w Polsce: filozofia człowieka w ujęciu fenomenologicznym oraz dialogicznym, koncentrująca się wokół problematyki podmiotowości i doświadczenia Innego, a także filozofia przyrody, obficie czerpiąca z osiągnięć współczesnych nauk przyrodniczych i bazująca na osiągnięciach współczesnej filozofii analitycznej j7. Wspólne dla obydwu nurtów - reprezentowanych z jednej strony przez Tischnera i jego uczniów, z drugiej zaś przez środowisko skupione wokół Hellera i Życińskiego - okazało się porzucenie metod i aparatu pojęciowego filozofii tomistycznej jako nieadekwatnej dla

\footnotetext{
${ }^{56}$ Por. T. Gadacz, A. Michalik, W. Skoczny, Wydział Filozofii Papieskiej Akademii Teologicznej (prezentacja), „Logos i Ethos” 1 (1991), s. 164-189; Wydziat Filozoficzny Papieskiej Akademii Teologicznej w Krakowie. Informator 1988/89, s. 5-6.

${ }^{57}$ Por. np. J. Woleński, Ogólny obraz filozofii polskiej w latach 1945-1989, w: J. Skoczyński, J. Woleński, Historia filozofii polskiej, Kraków 2010, s. 543. Dla uzupełnienia warto dodać, iż grupy te łączyło między innymi zainteresowanie problematyką Boga. Por. S. Kowalczyk, Nurty filozofii Boga w Polsce w latach 1880-2000, Lublin 2009, s. 122-147.
} 
rozwiązania problemów płynących ze strony współczesności. „Postanowiłem filozofować bez etykiety” - przyznawał Józef Tischner, który w latach osiemdziesiątych kształtował swoją filozofię dramatu w dialogu z fenomenologią, filozofią spotkania, egzystencjalizmem czy hermeneutyką filozoficzną. Podobną drogę obrała grupa filozofów przyrody. O ile jeszcze ks. Kłósak, czyli de facto pierwszy przedstawiciel tej specjalizacji w środowisku kształtującego się Instytut Filozofii przy Papieskim Wydziale Teologicznym, bazował na lowańskiej wersji filozofii tomistycznej ${ }^{58}$, o tyle już jego uczeń czyli ks. Wojciechowski reprezentował w swoich poglądach antropologicznych większą swobodę, jeśli chodzi o wybór metody filozofowania ${ }^{59}$.

Samodzielność badań - niekiedy jednak przy czerpaniu z owoców tradycji - przejawiali zwłaszcza Heller i Życiński, którzy w pewnym sensie stali się także kontynuatorami myśli zapoczątkowanej przez ks. Pawlickiego (oraz - niezależnie od tego - przedstawicieli krakowskiej filozofii przyrody okresu międzywojennego ${ }^{60}$ ). Zaproponowana przez nich „filozofia w nauce” okazała się nie tylko nowatorską metodą uprawiania filozofii przyrody, ale również swego rodzaju szkołą skupiającą filozofów i naukowców, mającą do dziś kontynuatorów oraz licznych naśladowców ${ }^{61}$. Warto jednak dodać, że myśl św. Tomasza z Akwinu nadal cieszyła się na Wydziale Filozoficznym poważaniem, choć nie była traktowana jako zamknięty system myślowy. Do tak rozumianego tomizmu nawiązywali np. ks. Marian Jaworski ${ }^{62}$, a polemicznie także Karol Tarnowski ${ }^{63}$. Szacunkiem cieszył się również personalizm, w ujęciu bioetycz-

${ }^{58}$ Por. np. K. Kłósak, Z teorii i metodologii filozofii przyrody, Poznań 1980.

${ }^{59}$ Por. np. T. Wojciechowski, Wybrane zagadnienia z filozoficznej antropologii, Kraków 1985.

${ }^{60}$ Por. np. J. Mączka, M. Heller, Przedmowa, w: Krakowska filozofii przyrody..., dz. cyt., s. 1-3; J. Mączka, Historia filozofii przyrody w Polsce. Krakowska szkoła filozofii przyrody, nauk przyrodniczych i matematyki, w: A. Dziedzic i in. (red.), Historia filozofii polskiej. Dokonania poszukiwania - perspektywy, Warszawa 2007, s. 95-104; P. Polak, Skąd wziąt się krakowski styl uprawiania filozofii przyrody?, w: S. Wszołek, R. Janusz (red.), Wyzwania racjonalności. Księdzu M. Hellerowi współpracownicy i uczniowie, Kraków 2006, s. 439-449.

${ }^{61}$ Zarys programu "filozofii w nauce” jako metody filozoficznej - por. np. M. Heller, Jak możliwa jest „filozofia w nauce”?, „Studia Philosophiae Christianae” 22 (1986), s. 7-19.

${ }^{62}$ Ks. M. Jaworski dostrzegał przy tym potrzebę uzupełnienia tomizmu o doświadczenie egzystencjalne. Por. np. tenże, Tomistyczna koncepcja człowieka, „Colloquium Salutis”, t. 13 (1981), s. 251-265; tenże, Doświadczenie religijne w ujęciu fenomenologicznym, w: B. Bejze (red.), W kierunku religijności, Warszawa 1983, s. 60-74.

${ }^{63}$ Por. np. K. Tarnowski, Tomizm a obecność filozofii, „Znak” 2 (1978), s. 198-212. 
nym rozwijanym przez ks. Krzysztofa Szczygła ${ }^{64}$. Nie sposób pominąć także wkładu ks. Józefa Makselona w zakresie psychologii empirycznej, zwłaszcza psychologii religii i tanatopsychologii, których ks. Makselon był jednym z pionierów w skali krajowej ${ }^{65}$. Tych kilka przykładów pokazuje, jak zróżnicowane środowisko organizowało się wokół Wydziału Filozoficznego Papieskiej Akademii Teologicznej u progu jego działalności.

Oferta dydaktyczna, w związku z tak szerokim obszarem zainteresowań pracowników wydziału, musiała być więc bardzo bogata. I rzeczywiście tak było. Co więcej, studenci mieli okazję brać udział w licznych zajęciach pomocniczych, np. z podstaw matematyki i fizyki, statystyki, astronomii czy biologii i genetyki molekularnej. Prowadzono ponadto szereg wykładów monograficznych o zróżnicowanej tematyce. Warto wymienić tytuły chociaż niektórych: „Paradygmat nauki i wiary” (ks. J. Życiński, 1982/83), „Struktura czasoprzestrzeni” (ks. M. Heller, 1983/84), „Zagadnienie praw człowieka” (ks. A. Usowicz, 1983/84), „Zasady ewolucyjnej teorii poznania” (ks. T. Wojciechowski, 1983/84), „Zagadnienie doświadczenia religijnego” (M. Jaworski, 1983/84), „Elementy tanatologii” (ks. J. Makselon, 1984/85), „Neurofizjologiczne aspekty psychiki” (K. Szczygieł, 1984/85), „Człowiek jako podmiot dramatu” (ks. J. Tischner, 1984/85), „Główne kierunki filozofii przyrody” (o. M. Pieńkowski, 1985/86), „Religia i metafizyka F. Rosenzweiga” (ks. T. Gadacz, 1986/87), „Filozoficzne aspekty genetyki” (ks. P. Lenartowicz, 1987/88), „Historia filozofii Boga” (K. Tarnowski, 1987/88), „Elementy kosmologii przyrodniczej” (Z. Golda, 1988/89), „Człowiek w analizie egzystencjalnej V. Frankla” (o. H. Piszkalski, 1988/89), „Klasycy myślenia politycznego" (Z. Stawrowski, 1988/89), „Człowiek a państwo w filozofii J. Maritaina” (ks. W. Zuziak, 1990/91), „Trzy koncepcje nauki: Arystoteles, Newton, Popper” (ks. W. Skoczny (1990/91), „Mistyka - dialog czy monolog?” (o. J.A. Kłoczowski, 1990/91) ${ }^{66}$. Studenci mieli więc do dyspozycji szeroki wybór tematyczny wykładów z najróżniejszych dziedzin filozofii. Z Wydziałem Filozoficznym współpracowało wówczas wielu uczonych spoza Papieskiej

\footnotetext{
${ }^{64}$ Por. J. Brusiło, Bioetyka i etyka lekarska Krzysztofa Szczygła, w: T. Biesaga (red.), Bioetyka polska, Kraków 2004, s. 27-43.

${ }^{65}$ Por. np. J. Makselon, Struktura wartości a postawa wobec śmierci. Studium z tanatopsychologii, Lublin 1983; tenże, Lęk wobec śmierci. Wybrane teorie i badania psychologiczne, Kraków 1988; tenże, Religijność a postawa wobec śmierci, „Analecta Cracoviensia”, t. 10 (1978), s. $117-131$.

${ }^{66}$ Por. T. Gadacz, A. Michalik, W. Skoczny, Wydział Filozofii..., dz. cyt., s. 176-179.
} 
Akademii Teologicznej. Wykłady monograficzne dla studentów filozofii prowadzili m.in. Zofia Włodek, Elżbieta Wolicka, Jan Reczek, Adam Węgrzecki, Piotr Flin. Warto też odnotować, że już u progu lat osiemdziesiątych ze środowiskiem PWT współpracował Paweł Taranczewski, który m.in. przełożył na język polski podręcznik do antropologii filozoficznej autorstwa Alwina Diemera. Podręcznik ten - jak pisał we wprowadzeniu Józef Tischner - „ukazuje się na prawach rękopisu i służy do użytku wewnętrznego studentów Papieskiego Wydziału Teologicznego w Krakowie"67. Należy w tym miejscu zaznaczyć, że na Wydziale Filozoficznym Papieskiej Akademii Teologicznej każdy etap studiów był otwarty przed osobami świeckimi ${ }^{68}$. Podjąć naukę mogli jednak wyłącznie absolwenci innych kierunków bądź studenci, którzy mają za sobą zaliczony co najmniej 3 rok studiów ${ }^{69}$.

Obok cyklu zasadniczego, wieńczonego magisterium, nie mniej istotną rolę w dziejach kształtującego się ośrodka filozoficznego miały także obrony prac doktorskich i kolokwia habilitacyjne. W okresie między 1976 a 1991 rokiem na Papieskim Wydziale Teologicznym (a od 1981 roku w Papieskiej Akademii Teologicznej) obronione zostały rozprawy doktorskie o charakterze filozoficznym, których autorami byli: ks. J. Życiński (1976), ks. A. Smandek (1978), ks. R. Rożdżeński (1981), ks. K. Bukowski (1982), K. Turek (1983), ks. T. Gadacz SP (1984), o. Z. Górnicki OP (1985), ks. F. Gruszka (1985), ks. W. Paluchowski (1985), ks. W. Skoczny (1986), ks. H. Gardyjas (1987), ks. M. Olejnik (1989), ks. J. Bednarczyk (1990), A. Bobko (1991). W analogicznym okresie odbywały się również kolokwia habilitacyjne ks. J. Życińskiego (1980), o. H. Piszkalskiego (1983), ks. P. Lenartowicza SJ (1985), ks. J. Makselona (1987), K. Tarnowskiego (1988), ks. S. Pamuły (1989), ks. R. Rożdżeńskiego (1989), o. J.A. Kłoczowskiego OP (1990), ks. R. Darowskiego SJ (1990), ks. T. Gadacza SP (1990), ks. A. Jarnuszkiewicza SJ (1991), ks. M. Jędraszewskiego (1991). Warto zaznaczyć, że stopnie naukowe zdobywane na Papieskiej Akademii Teologicznej uznane zostały przez państwo dopiero w 1989 roku; w umowie z 30 czerwca

${ }^{67}$ Por. A. Diemer, Kurs elementarny filozofi - antropologia filozoficzna, tłum. P. Taranczewski, Kraków 1981.

${ }^{68}$ Co ciekawe, już pod koniec lat osiemdziesiątych studia filozoficzne podejmowało więcej osób świeckich niż alumnów i księży. Por. Wydział Filozoficzny Papieskiej Akademii Teologicznej w Krakowie. Informator 1988/89, s. 8-10.

${ }^{69}$ Dopiero u progu lat dziewięćdziesiątych, w obliczu spadku zainteresowania kierunkiem filozoficznym na Papieskiej Akademii Teologicznej, podjęto poważne dyskusje na temat otwarcia drogi na te studia osobom po maturze. 
zrównano tytuły uzyskiwane na tej uczelni z tytułami nadawanymi przez państwowe szkoły wyższe. Wieloletnie starania środowiska Papieskiej Akademii Teologicznej w sprawie uzyskania należnych praw zaczęły przynosić więc upragnione rezultaty. Kontynuacja tego procesu na szerszą skalę nastąpić miała zwłaszcza w kolejnej dekadzie.

\section{Zamiast zakończenia}

Dziesięć lat po wydaniu motu proprio „Beata Hedvigis” Wydział Filozoficzny był już stabilną, cenioną jednostką naukowo-dydaktyczną, posiadającą szeroką kadrę uczonych oraz własne instytucje badawcze i czasopi$\mathrm{sma}^{70}$. Ośrodek filozoficzny przetrwał wyjątkowo trudne czasy komunizmu oraz transformacji ustrojowej, z nadzieją patrząc w przyszłość i kolejne wyzwania, jakie się przed nim rysowały. Dziś, po upływie kolejnych kilku dekad wiemy, że podjęty wtedy wysiłek się opłacił. Na przestrzeni lat zrealizowano bowiem szereg zaawansowanych projektów badawczych, wypracowując przy tym własny, oryginalny styl myślenia; rozwinięto także ofertę dydaktyczną i powiększono grono wykładających. Co ciekawe, w 2008 roku Wydział Filozoficzny po raz kolejny nawiązał do swych historycznych związków z Uniwersytetem Jagiellońskim poprzez utworzenie - z inicjatywy ks. Michała Hellera - wspólnej jednostki naukowej, jaką jest Centrum Kopernika Badań Interdyscyplinarnych. Z kolei podniesienie Papieskiej Akademii Teologicznej do rangi Uniwersytetu Papieskiego 19 czerwca 2009 roku nie tylko wzmocniło pozycję Wydziału Filozoficznego w polskim środowisku naukowym, ale także uświadomiło, jak daleką drogę przebył on do obecnego stanu.

Dziś owemu Wydziałowi z okazji 40. urodzin warto życzyć kolejnych sukcesów oraz następnych uczonych na miarę księży Tischnera czy Hellera. Przypuszczam, że wielu zawdzięcza swoją fascynację zarówno filozofią, jak i naukami szczegółowymi właśnie tym postaciom krakowskiego środowiska. Podobno żaden sługa nie może dwóm panom służyć, w tym wypadku jednak pozwolę sobie poczynić mały wyjątek i wyrazić wdzięczność tak dla jednego, jak i dla drugiego z Filozofów - za piękny przykład zaangażowanego i pełnego pasji myślenia o człowieku oraz otaczającym świecie, a także za wezwanie do samodzielności i odwagi w kroczeniu nieprzetartymi szlakami wiedzy. Wszak

${ }^{70}$ W 1991 roku ukazuje się pierwszy numer czasopisma „Logos i Ethos”, nadal wydawane były „Zagadnienia Filozoficzne w Nauce”. 
„kto zdecydował się na filozofowanie, powinien zejść z grzbietu klasyka”71. Aby jednak zejść, trzeba się tam najpierw wspiąć. Doskonały przykład, jak tego dokonać, już otrzymaliśmy. Teraz wszystko w rękach - a właściwie głowach kontynuatorów.

${ }^{71}$ Por. J. Tischner, Czym jest filozofia, którą uprawiam, „Znak” 11-12 (1977), s. 1354-1358. DOI: http://dx.doi.org/10.15633/9788374386487.03 